\title{
鉛フリー材料およびそのソルダリング継手の基本特性からの 鉛フリー化-鉛フリーはんだプロジェクト・日本溶接協会の活動
}

\author{
藤本 公三*
}

Lead Free Soldering Based on Fundamental Properties of Lead Free Solder Materials and Their Soldered Joints

Kozo FUJIMOTO*

*大阪大学大学院工学研究科生産科学専攻（勇565-0871 大阪府吹田市山田丘2-1）

*Department of Manufacturing Science, Graduate School of Engineering, Osaka University (2-1 Yamada-Oka, Suita-shi, Osaka 565-0871)

\section{1. はじめに}

近年，エレクトロニクス製品は電子デバイスの高密度・ 高集積化により小型・高機能な製品が次々と開発され，人 間の生活はより一層豊かになってきている。しかし，これ らの電子製品の製造において，電子部品のプリント配線板 への実装時に用いられているはんだに有害金属である鉛が 含まれており，このはんだに含まれている鉛は，寿命を迎 えた電子・電気製品の廃裹埋め立てに伴う地中への流出に よる地下水污染として問題視されている。

このような状況下で, NEDO（新エネルギ開発機構）委 託事業「鉛フリーはんだの規格化のための研究開発」が産 業環境管理協会に委託され，日本溶接協会がその再委託先 の 1 つとして研究プロジェクトが設立された。

これまで, 鉛フリー化に対する研究は欧米での研究プロ ジェクト, 日本での各研究機関, 会社で取り組みが行われ てきた。しかし，これまでの取り組みは，標準となる試験 方法，実験条件の整合がなされないままに行われてきたた め, 実用化に対する判断が各社各様となっており，様々な 組成の鉛フリー材料の提案がなされている。使われるはん だ材料が種々雑多になれば，それに対するフラックス，電 極めっきの組み合わせなども考えると無限の組み合わせの 中での実装となることが想定される。鉛フリー化をすべて
の製品レベルで実用化するには，ソルダリングの原理原則 に立ち返り，標準となる試験・評価法に基づいて標準とな るはんだ組成, 電極材料, 実装条件などを見直す必要があ る。

そこで，日本溶接協会のプロジェクトでは，鉛フリーは んだの評価試験方法を標準化, ならびに種々提案されてい る鉛フリーはんだの特性の標準化を図ることにより，鉛フ リーはんだの実用化への共通尺度を構築することを目的と して研究を行った。

なお, 本研究プロジェクトでは現状のSn-Pb共晶はんだ による実装（材料構成，実装条件など）をべースにするの ではなく，鉛フリー候補合金材料の特性をべースにして， その材料を用いたときに, 適用可能となる実装条件範囲, 材料構成などを明確にすることを目指したものである。

\section{2. ソルダリングの原理原則に基づく基本特性の標準 化指針}

鉛フリー化を実現するには，鉛フリーはんだ材料を用い て実装を行ったときの実装継手の品質，信頼性の要求を満 足することが必要となる。実装においては, 図 1 に示すよ うに，製品によって設計仕様，要求仕様・性能，装置の性 能が異なり, これら各仕様・性能に対して, 用いる材料, プロセス条件が選定されなければならない。これらの選定

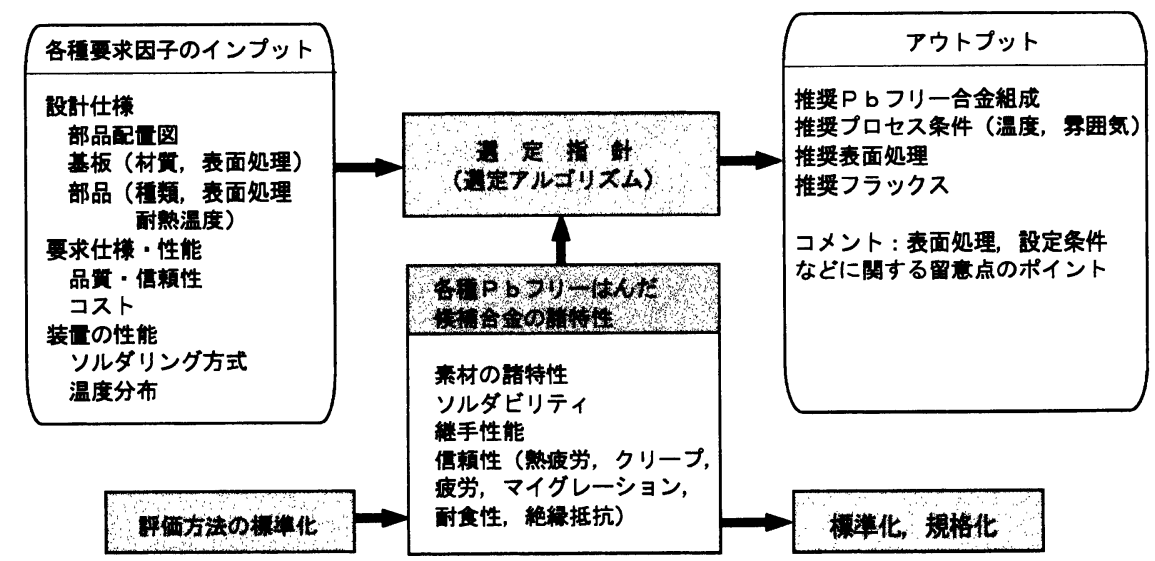

図1. 鉛フリーはんだ規格化のための研究開発プロジェクトの指針 
のためには，各種鉛フリーはんだ候補合金の材料特性，ソ ルダビリティ, 継手性能, 信頼性等の基礎データを明確に しておく必要がある。これら基礎となるデー夕は，デー夕 を取得する装置，データを取得する者が異なっても同一の データが得られる標準試験・評価法に基づく標準データで ある必要がある。

標準試験・評価法の策定, およびそれから得られた標準 となる特性を評価するには，ソルダリングの原理原則に立 脚していることが最も重要となる。

電子部品のプリント配線板への実装に使われているソル ダリングプロセスは, 図 2 に示すように, 電子部品, プリ ント配線板とはんだという 3 種類の材料をある温度に加熱 することで, 図 3 に示すように, 部品や基板の電極材料と はんだとの界面反応（ぬれ, 溶解, 拡散）が生じ, 接続が 達成される。接続されたソルダリング継手の品質, 信頼性 やソルダリング時の作業性は, はんだ，フラックスの材料 特性, 電子部品, プリント配線板の電極材料の材料特性と その表面性状および加熱時の温度プロファイルにより大き く変化をする。つまり, ソルダリング品質を支配している のは, 各種材料特性とそれに与える熱 (温度プロファイル) である。ぬれ, 溶解, 拡散などの界面反応は与えられた材 料, 温度プロファイルの結果として現れる現象である。従 来の報告の大半はこの温度をソルダリング時の代表温度 （リフロー炉の温度プロファイル，フロー槽のはんだ浴温 度）で規定しており，個々の接合部の温度に大きな違いが でている。この温度の違いが各種の特性, 現象の変化を引 き起こし，本質的な影響因子の判明を阻害してきた感があ

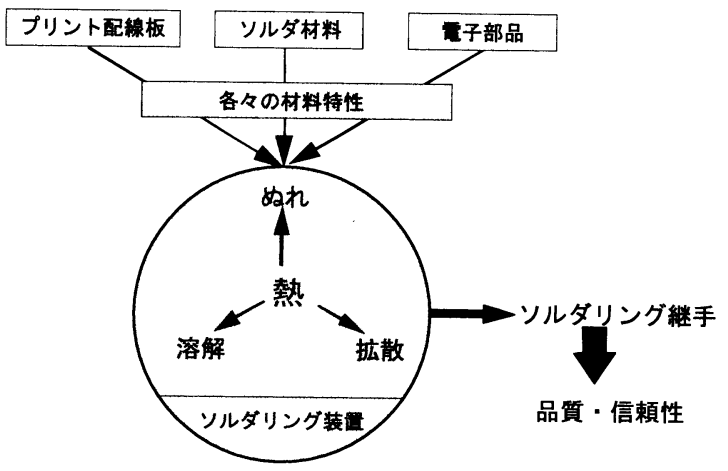

図2. ソルダリングの原理

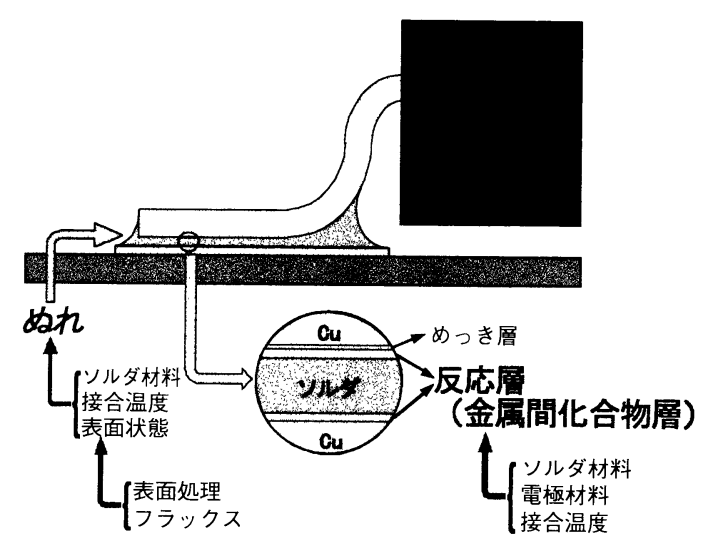

図3.ソルダリング継手における界面反応
る。このため, 本研究プロジェクトでは, 実際の接合部温 度を測定し, 各種継手作成条件を接合部温度で規定し，接 合部温度を $10^{\circ} \mathrm{C}$ 刻みで変化させることで，各種特性，界面 現象を評価し，鉛フリーはんだ特性の標準化を図ることを 基本としている。

\section{3. 共通試験用鉛フリーはんだ材料}

鉛フリーはんだは, Sn-Ag系，Sn-Ag-Bi系，Sn-Ag-Cu 系, Sn-Ag-Cu-Bi系, Sn-Zn系, Sn-Bi系など各種の合金組 成のはんだが提案され, 検討されてきている。いずれの合 金材料も現在，プリント配線板実装に使われているSn-Pb 共晶はんだに取って代わるものはない。

はんだ材料だけをとってみると，Sn-Pb共晶はんだより も機械的特性，信頼性が高い合金組成のはんだがいくつも あるが, $\mathrm{Sn}-\mathrm{Pb}$ 共晶はんだよりも融点が高く, 部品および プリント配線板上の電極材料に対するぬれ性が悪いという 課題がある。ソルダリング温度をはんだ合金の融点に合わ せて高くすることが可能であれれば，十分使用できる鉛フ リーはんだとして用いられるはんだ合金はある。しかし， 電子部品の耐熱温度等の観点から $\mathrm{Sn}-\mathrm{Pb}$ 共晶はんだを用い たソルダリングで設定されているソルダリング条件で行お うとすると，はんだ材料が電極材料に十分ぬれず，接合が 困難となっている。鉛フリーはんだの融点を下げるために は，低融点金属であるBiやInを添加することになるが，添 加量が多くなると, 材料の伸びが悪くなり, 脆性的挙動を 示すため，信頼性が低下することになる。

このように，現状のSn-Pb共晶合金を用いたソルダリン グプロセスをベースとしたときに，Sn-Pb共晶はんだと比 較して同等以上の性能を有する鉛フリーはんだ材料が金属 学的に存在していないのが, 鉛フリー化の最も難しい点で ある。

従来より公表されていて, 実用化に適すると考えられる いくつかの鉛フリーはんだ候補合金を，溶融温度範囲およ び合金系に分けて分類したものを表 1 に示す。

これらの中から，溶融温度範囲，従来の報告，合金価格 等を考慮して, 実用化に近い位置にあると考えられる表 2 の合金を第 1 次共通継手作成用鉛フリーはんだ合金とし て，フローおよびリフロー法用それぞれの工法について選 定した。Sn-Ag-Bi系では工法を考慮してBi含有量を変えて いる。これらのはんだ材料は，継手試験用共通試験基板に 部品を搭載して大気中ソルダリングされ，継手評価が行わ れる。なおフローおよびリフロー用の基板と部品は異なる。

\section{4. 研究開発内容}

本研究プロジェクトでは，図 1 に示したように，各種鉛 フリー合金材料に対する材料特性，継手特性・信頼性の標 準となるデータをまとめることを主眼として研究開発を行 つた。 
表1. 実用化に適すると考えられる合金系と溶融温度範囲別分類

\begin{tabular}{|c|c|c|c|c|}
\hline \multirow{2}{*}{ 溶融温度範囲 } & \multicolumn{4}{|c|}{ 合金系 } \\
\hline & Sn-Ag(-Cu) & Sn-Ag-Bi, In* & Sn-Zn*\# & その他 \\
\hline \multirow{2}{*}{$\begin{array}{c}\text { 高温系 } \\
\text { （液相線 } 227^{\circ} \mathrm{C} \text { 以上） }\end{array}$} & & & & Sn-5Sb \\
\hline & & & & $\mathrm{Sn}-0.7 \mathrm{Cu}$ \\
\hline \multirow{3}{*}{$\begin{array}{c}\text { 中高温系 } \\
\text { (液相線 } 227^{\circ} \mathrm{C} \text { 未満 } \\
217^{\circ} \mathrm{C} \text { 越える) }\end{array}$} & Sn-3.5Ag & & & \\
\hline & $\mathrm{Sn}-3.5 \mathrm{Ag}-0.6 \sim 1 \mathrm{Cu}$ & & & \\
\hline & $\mathrm{Sn}-2 \mathrm{Ag}-0.8 \mathrm{Sb}-0.5 \mathrm{Cu}$ & & & \\
\hline \multirow{4}{*}{$\begin{array}{c}\text { 中温系 } \\
\text { (液相線 } 177^{\circ} \mathrm{C} \text { 以下 } \\
183^{\circ} \mathrm{C} \text { 越える) }\end{array}$} & & $\mathrm{Sn}-2 \sim 3.5 \mathrm{Ag}-2 \sim 5 \mathrm{Bi}$ & & \\
\hline & & Sn-2 $\sim 3.5 \mathrm{Ag}-2 \sim 5 \mathrm{Bi}-\mathrm{X}$ & & \\
\hline & & Sn-3.5Ag-2.5Bi-2.5In & & \\
\hline & & $\mathrm{Sn}-2 \mathrm{Ag}-7.5 \mathrm{Bi}-0.5 \mathrm{Cu}$ & & \\
\hline $\begin{array}{c}\mathrm{Sn}-\mathrm{Pb} \text { 共晶並系 } \\
\text { (固相線 } 183^{\circ} \mathrm{C} \text { 近傍) }\end{array}$ & & & $\begin{array}{c}\mathrm{Sn}-8 \mathrm{Zn}-3 \sim 6 \mathrm{Bi} \# \\
\text { (フロー法：不向き) }\end{array}$ & \\
\hline $\begin{array}{c}\text { 低温系 } \\
\text { (固相線 } 140^{\circ} \mathrm{C} \text { 以下) }\end{array}$ & & & & $\begin{array}{c}\text { Sn-58Bi } \\
\text { (特殊用途) }\end{array}$ \\
\hline
\end{tabular}

* : $\mathrm{Cu}$ 微量添加 $(0.5 \%$ 程度) も含む $\mathrm{X}:$ 添加元素 \#: 実用化には問題山積

表2. 共通試験継手作成用に選定した鉛フリーはんだの組成

\begin{tabular}{c|c|c|c}
\hline 合金系 & フロー用 & リフロー用 & 備考 \\
\hline $\mathrm{Sn}-\mathrm{Ag}$ & \multicolumn{2}{|c|}{$\mathrm{Sn}-3.5 \mathrm{Ag}$} & \\
\hline $\mathrm{Sn}-\mathrm{Ag}-\mathrm{Cu}$ & $\mathrm{2n}-3.5 \mathrm{Ag}-0.7 \mathrm{Cu}$ & \\
\hline $\mathrm{Sn}-\mathrm{Ag}-\mathrm{Bi}$ & $\mathrm{Sn}-3 \mathrm{Ag}-3 \mathrm{Bi}$ & $\mathrm{Sn}-3 \mathrm{Ag}-5 \mathrm{Bi}$ & \\
\hline $\mathrm{Sn}-\mathrm{Ag}-\mathrm{Bi}-\mathrm{In}$ & - & $\mathrm{Sn}-3.5 \mathrm{Ag}-2.5 \mathrm{Bi}-2.5 \mathrm{In}$ & フロー用には検討しない \\
\hline $\mathrm{Sn}-\mathrm{Pb}$ & \multicolumn{2}{|c|}{$\mathrm{Sn}-37 \mathrm{~Pb}$} & 比較検討用 \\
\hline
\end{tabular}

まず，各種実験に先立ち，標準となる材料の評価試験方 法, 継手作製のための実装条件の規定および標準継手評価 方法の策定を行った。試料作成, 継手作成および特性評価 はすべて複数機関において，本プロジェクトで策定した標 準試験・評価方法に基づいて行った。

鉛フリー合金材料の特性評価としては, Sn-Ag-Cu系, Sn-Ag-Bi系, Sn-Ag-Cu-Bi系, Sn-Zn系, Sn-Bi系の鉛フリ 一はんだ材料における材料特性（溶融温度範囲，機械的特 性，ぬれ性）を合金成分の組成比の変化，およびGe，P， Znなどの微量添加元素の影響も含めて評価した。

継ぎ手特性としては，はんだ合金材料特性，実装温度， 材料の表面状態が支配因子である。特に，実装温度はソル ダリングにおけるすべての因子に影響を与えるため，実装

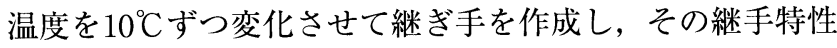
の評価を行った。特に，この実装温度は，ソルダリングに とって最も意味のある接合部の実温度を測定して評価パラ メータとした。実装ラインでの条件管理は加熱炉の設定温 度やフローソルダリング浴の溶融はんだ温度で行っている が，これらの設定值を同じにしても，接合部温度は装置に より異なるため，標準としての温度条件とはならない。リ フローソルダリングでは，この実装温度による影響と表面 状態による継ぎ手特性の評価を行った。表面状態は，材料 の表面処理, フラックス, 実装温度プロファイルにより変 化し，これら個々の因子は相互に関係し合っているため， 個々の因子を独立に取り扱うことができない。このため，
実装時の材料表面の評価パラメータとして, 実装温度プロ ファイル下でのぬれ性評価デー夕を取得し，実装時のぬれ 挙動の解析と実装時のぬれと継手特性の関係を検討した。 フローソルダリングでは，実装温度の影響をベースにし， 窒素雲囲気の影響, はんだ組成とめっき組成が継手性能に 与える影響について評価を行った。

\section{5. プロジェクトで得られた主要結果}

本研究プロジェクトでは，鉛フリーはんだの材料特性, 継手特性の標準となる評価・試験方法の指針を得ること, さらに，標準評価・試験方法による基本鉛フリーはんだの 材料および継手特性を明確にし，標準化・実用化の指針を 示すことを目的として実験を行った。

材料特性・継手特性の標準評価・試験方法に対しては, 本プロジェクトで選定した評価・試験方法においては，同 一評価機関内での評価結果ではばらつきが少なく，異なる 評価機関間での傾向の一致を見ることができ，評価・試験 方法としての基本は問題なかったが，異なる評価機関間で の評価值の絶対值ばらつきが生じており，個々に，評価ば らつきをなくすための規定を追加する必要があることがわ かった。

Sn-Ag-Cu系, Sn-Ag-Bi系, Sn-Ag-Cu-Bi系, Sn-Ag-BiIn系, Sn-Bi系, Sn-Zn系の各鉛フリーはんだの材料特性 （溶融温度範囲，機械的特性，ぬれ性）を評価した。溶融 温度範囲に関しては，各系の状態図を作成したが，計測精 
度が $0.55^{\circ} \mathrm{C}$ 程度あることを考慮する必要がある。機械的 特性に関しては, Sn-AgをべースにしたSn-Ag-Cu系, SnAg-Bi系, Sn-Ag-Cu-Bi系, Sn-Ag-Bi-In系の鉛フリーはん だはSn-Pb共晶はんだよりも引張強さは大きく，伸びは同 程度を呈している。しかし, Sn-Pb共晶はんだは, 試験温 度を $80^{\circ} \mathrm{C}, 120^{\circ} \mathrm{C}$ 高くするほど延性は良くなるが, これ らの鉛フリーはんだ材料では, 試験温度による延性の変化 はあまりなかった。また, Bi添加においては, Biの添加量 が多くなるほど引張強さは大きくなるが, 延性が低くなる。 ぬれ性に関しては，いずれもSn-Pb共晶はんだより悪い結 果を示したが, ウェッティングバランス試験において, （試験温度－融点）で性を評価すると，いずれの鉛フ リーはんだ材料もSn-Pb共晶はんだと同等のぬれ性を呈す ることが明確になった。また，リフローソルダリング時の ぬれ性を検討する場合は，はんだ材料とめっき材料の界面

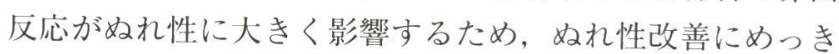
材料の選定が非常に重要であることを明らかにした。

Sn-3.5Ag-0.7Cu, Sn-3.5Ag-5Bi, Sn-3Ag-2.5Bi-2.5Inの各 鉛フリーはんだにおけるリフローソルダリングにおいて, 各はんだ材料の融点 $+10^{\circ} \mathrm{C}$ の接合部温度で実装を行った場 合, ぬれ性はSn-Pb共晶はんだに劣るものの熱・機械的信 頼性はSn-Pb共晶はんだと同等以上の継手が得られる。な お, Sn-Ag-Bi系のはんだにおいて, 鉛を含むめっき材料に 対してBiの含有量が増えると熱・機械的信頼性が低下す る。

Sn-3.5Ag, Sn-3Ag-3Bi, Sn-3.5Ag-0.7Cu, Sn-0.3Ag0.7Cu, Sn-0.7Cuの各鉛フリーはんだにおけるフローソル ダリングにおいて, 各はんだ材料の融点 $+15^{\circ} \mathrm{C}$ の接合部温 度で実装を行った場合, ぬれ性はSn-Pb共晶はんだに劣る ものの熱・機械的信頼性はSn-Pb共晶はんだと同等もしく

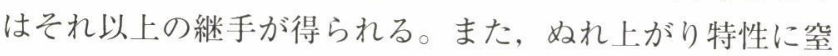
素䨌囲気の利用が効果があること, リフトオフには, はん だ組成とめっき組成の組み合わせが大きく影響することを 明らかにした。

基本的には, 実装温度を鉛フリーはんだ材料の融点 $+\alpha$ (リフローソルダリングの場合は $10^{\circ} \mathrm{C}$, フローソルダリン グの場合は $15^{\circ} \mathrm{C} ）$ の接合部温度で実装することにより， $\mathrm{Sn}-\mathrm{Pb}$ 共晶はんだと同等以上の信頼性を有する継ぎ手を得 ることが可能である。しかし, 実装温度の上限が部品耐熱 温度で規定されているため, 実装温度裕度がSn-Pb共晶は んだより狭く, 基板全面における温度の均一化, 材料の管 理が非常に重要となる。また, 鉛フリーはんだに適しため っき材料の選定，パッド設計等が必要となる。

さらに，やに入りはんだの可能性検討において，Sn$3.5 \mathrm{Ag}-0.7 \mathrm{Cu}, \mathrm{Sn}-3.5 \mathrm{Ag}-3 \mathrm{Bi} の$ やに入りはんだは $0.3 \mathrm{~mm} \phi の$ ものまで加工が可能であるが，Biを増やしたSn-3.5Ag-5Bi においては, 加工時の割れ等が発生し, 細線化が困難であ った。また，Sn-3.5Ag-0.7Cu，Sn-3.5Ag-3Biのやに入りは
んだによるソルダリング性はSn-Pb共晶はんだよりやや劣 るものの作業手順，および条件管理を適正にすれば問題な く使えることを明らかにした。

\section{6. おわりに}

日本溶接協会における研究プロジェクトでは, プロジェ クトへの参画メンバーすべての共通の評価・試験方法を設 定し, その評価・試験方法に基づいて, 鉛フリーはんだ材 料の材料特性およびリフローソルダリング, フローソルダ リングしたソルダリング継手の品質・信頼性を評価し， $\mathrm{Sn}-\mathrm{Pb}$ 共晶はんだの代替鉛フリーはんだの候補合金材料の 基礎特性を明確にするとともに, 評価・試験方法の規格化 のための課題を明確にした。

ソルダリングプロセスにおいて，品質を作用するのは， はんだ材料と被接合材である基板・部品上の電極材料との 間で生じる界面反応（ぬれ，溶解，拡散）である。この界 面反応は, 実装時に接合部に加えられる温度プロファイル で大きく影響される。さらに，エレクトロニクス製品を製 造する場合, 製品により個々の接合部の温度が大きく異な る。このため, 本研究プロジェクトで明確にした接合部温 度を評価パラメータとした材料および継手特性は, 実用化 を検討する際の基礎データとして, 非常に有効であると考 えられる。

ソルダリングにおける鉛フリー化は環境問題における鉛 の使用撤廃とだけとらえると，エレクトロニクス製品製造 における環境問題としては小さな問題かもしれない。リサ イクル技術，エコデザインなどの製造システムとしての取 り組みが, より重要であると考えられる。しかし，この鉛 フリー化は実装技術の高度化にとっては非常に大きな足場 になると考えられる。つまり，これまで使われてきたSn-

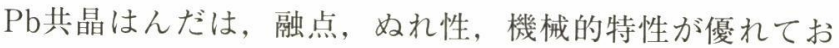
り，実装に扔ける条件管理，材料管理に対する裕度が広か ったが, 現在, 候補としてあげられている鉛フリー合金材 料は, いずれの材料を使っても各種管理裕度は低くなる。 このため, 実用化するには, ソルダ材料, 部品, 基板, ソ ルダリング装置の管理, 特に, 直接, 接合に関与する表面 の状態，接合部温度などで規定された管理が要求され， ウハウの世界から技術の世界への脱却が必要となるであろ j。

(2000.5.16-受理)

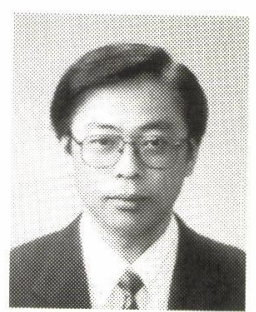

藤本 公三(ふじもとこうぞう)

昭和30年生まれ。昭和53年, 大阪大学工学部卒 業。現在、大阪大学大学院丁学研究科助教授。 知的微細システムに関する教育・研究に従事。 